\title{
In search of autochthony: A case study of the Great Migration Period as presented in history textbooks in Macedonia*
}

\begin{abstract}
The article examines the possible ties between recent political developments and education through a number of history textbooks form the R. of Macedonia. The research was narrowed down to one specific historical period (the Great Migration period/Late Antiquity) and therefore to the textbooks and chapters that deal with it. The textbooks concerned were published between 2001 and 2010. The textual and historiographical analysis of the historical narrative strongly suggests that some of the 'knowledge' conveyed to the pupils is influenced by politics, more precisely the need for autochthony. It is argued, in the paper, that two methods of fabricating continuity between contemporary and ancient peoples (ancient Macedonians - Macedonians and Illyrians - Albanians) are used in the chapters examined. At the same time, these methods are revealed and their functioning is explained. Certain controversial historical concepts are given space in order to develop specific national myths deemed useful for internal and external politics. Therefore, the article deals with the question of the abuse of history.
\end{abstract}

Key words: History, education, politics, nationalism, autochthony, ancient origin, Late Antiquity, Macedonia, history abuse

This paper is the result of a textual and historiographical analysis of specific sections of history textbooks used in the education system in the Republic of Macedonia in the period 2001-2010. It examines the chapters dealing with the Great Migration period ( $\mathrm{AD} 4^{\text {th }}-7^{\text {th }} \mathrm{c}$.) and especially the ones dealing with the arrival of the Slavs in the Balkans and their relationship with the local population. The principal aims of the study were to examine how the mentioned historical period is explained to the pupils, to compare the proposed knowledge to the generally accepted theories in historiography (Roman and Byzantine studies) today, and finally to put the result in the context of the current political situation in the region in order to see whether the education system is influenced by it or not. Therefore, in broad terms, this paper also deals with the use and abuse of history as well as with the transmission of knowledge and the creation of perception, culture and identity. In other words, it deals with the relations between nationalism, politics, science and education. 
For the purpose of this study eight history textbooks were examined, all of them published in post-conflict Macedonia. ${ }^{1}$ Not all published textbooks are examined because only a limited number of them contain information on the Great Migration period. The subject is usually taught in the $5^{\text {th }}$ or $6^{\text {th }}$ grade of elementary school and $1^{\text {st }}$ class of secondary school (depending on the official education plan). This gives us the age of the readers and receptors of the proposed historical knowledge, i.e. the pupils aged 11/12 and 15. These pupils come from different ethnic groups (Macedonians, Albanians, Turks, Serbs, Roma, etc.), and all of them use the same textbooks translated into their mother-tongues. ${ }^{2}$ On the following pages the main results of the study will be presented. Namely, I would argue that there is a link between contemporary politics, science and education, manifested in a search for autochthony/direct continuity with the ancient cultures of the region. In my opinion, two distinctive methods are used in some of the history textbooks to fabricate continuity. For now I will call them "Subtle approach" and "Fast forward approach".

\section{Subtle approach}

This approach uses inadequate, imprecise, all-inclusive, archaic and possibly manipulative terminology in order to convey to the pupils a sense of continuity with the ancient Macedonians and thus some sort of identification with them. It mainly focuses on the concept of "our fatherland", an all-encompassing term in which the differentiation between past and present, as well as between geography and politics, is unclear.

"Macedonia, our fatherland" 3 is a chapter title in a textbook. "Our fatherland" does this refer to a state, a nation, a territory? Is it abstract, or is it material? How is it defined in chronological and geographical terms? "The name of our fatherland is very old. It is mentioned for the first time in the $7^{\text {th }}$ century BC"/"Our fatherland has a long and rich history. In Antiquity it was a strong state". ${ }^{4}$ These phrases establish chronological and even 'genetic' links to the ancient Macedonians. It is implied that contemporary Macedonia and ancient Macedonia are equally 'our fatherland'. They create a chronological continuum from the $7^{\text {th }}$ century $\mathrm{BC}$ to this day and place the contemporary Macedonian state in a direct line with the ancient Macedonians' state.

1 In the first half of 2001 there was an armed conflict between Albanian insurgents and Macedonian security forces. As to the study, the original idea was to examine the textbooks published after the proclamation of independence in 1991, i.e. in post-socialist/post-Yugoslav Macedonia, but the lack of time limited the chronological frame of the research. I hope to continue this task in the near future.

2 It is equally worth noting that every team of historians responsible for the above-mentioned textbooks is composed of Macedonians and Albanians.

3 All translations from Macedonian into English in this paper are mine.

4 K. Adzievski, D. Petreska, V. Ačkoska, N. Dimoski, V. Gjorgiev, Istorija za petto oddelenie, Tabernakul: Skopje, 2005, p. 4. (History Textbook or HT $5^{\text {th }}$ grade) All HT titles in the footnotes are transcribed from the original Cyrillic to the Latin alphabet. 
The last sentence might even be interpreted as a contrast to the present condition of 'our state and fatherland' and as a romantic longing for a lost past.

After establishing the chronological and political connection to the ancient past, the textbook continues with pedagogy of the past in a rather specific, yet very common way, by transmitting patriotic values. The pupils are taught to love their fatherland and to fight for it ("Our ancestors loved their fatherland and fought for it"). But some specific questions arise: what if one part of the historical "fatherland" belongs to another state today (as is the case with the part of Macedonia that is a Greek province)? Should we fight for it too if necessary? On the other hand, should the Greek youth fight for it too, since de facto it is their present fatherland? The concept of fatherland might lead to territorial claims and conflict, especially if treated inadequately and abused by politics.

Furthermore, addressing 11-year-old pupils, the textbook ascertains that the main function of history as a scientific and educational discipline is to ensure love towards the fatherland (past or present): "He who knows history better will love his fatherland more". 5 Is this really the aim of history as a science? This might seem an acceptable definition to many politicians worldwide, but not to professional, open-minded scholars. This view of human history is rather limited and isolationist. Another important question: what should a pupil think about a fellow pupil who is not much interested in history, but rather in chemistry or music? "Is he/she less Macedonian/Italian/Irish/Chinese than me?” Even more, the quoted phrase implies that a good historian should also be a good patriot, more likely in the nationalistic sense of the term. Such values, propagated through education for decades, are one of the main reasons why generations of historians in the Balkans, and elsewhere, see themselves primarily as fighter for the nation, even today. It seems that this interpretation of history can become very complicated. It contributes much more to the development of nationalists and local patriots than critically thinking and responsible citizens.

Still, there are some positive aspects. When it comes to contemporary Macedonia, the textbook presents the country as a "historical" home for all its ethnic communities. "The Republic of Macedonia is a fatherland to the Macedonians, Albanians, Turks, Serbs, Roma, Vlachs and others. That's why we say that Macedonia is a multicultural state". ${ }^{6}$ Bearing in mind that some of the Balkan and even EU states do not recognize minorities inside their borders, I perceive this statement as a very democratic and tolerant approach. Yet, it remains questionable how many of the different ethnic groups would look for their 'fathers' in ancient Macedonia.

5 Ibidem, p. 6. I should stress on this occasion that the rest of the examined textbooks are not as strong and direct in conveying this message. Actually, in the "What is history" section, some are quite reasonable. Cf. B. Ristovski, S. Rahimi, S. Mladenovski, T. Chepreganov, M.B. Panov, Istorija za prva godina gimnazisko obrazovanie, Albi: Skopje, 2006, p. 6. (HT 1 $1^{\text {st }}$ class).

6 K. Adzievski et al., Istorija za petto oddelenie, p. 5. 
Contrary to this "subtle" approach towards historical continuity, or even history in general, the second approach is much more explicit and focused in its search for ancient roots.

\section{Fast forward approach}

On July $14^{\text {th }} 2006$ the Minister of Education and Science approved three history textbooks. One of these differed somewhat from its predecessors in one specific aspect and certainly deserves a closer examination. It elaborates hypotheses which are not accepted in historiography in general. Ironically, it is stated in the introduction of the textbook that although there might be different opinions and debates in history as science, in history as a subject of education only the undeniable scientific results are presented, whereas scientific controversies are presented only in exceptional cases. ${ }^{7}$ In the chapters on Late Antiquity and Early Middle Ages the textbook argues for the attested existence of the ancient Macedonians in the $\mathrm{AD} 6^{\text {th }} / 7^{\text {th }}$ century (!), attributing to them a strong and distinctive group identity and culture approximately 800 years after the fall of the ancient Macedonian kingdom of the Antigonids (168 BC). ${ }^{8}$ In a closer textual analysis, however, one might easily note several discrepancies.

For this purpose, I find it useful to quote one of the main theses of this claim:

"The imposition of Roman authority did not lead to the disappearance of the Macedonians as a people, because the Romans did not conduct politics of violent Romanisation of the population. As a result, the Macedonians continued to exist as a dominant people in Macedonia, strongly taking care of the Macedonian traditions of the times of Philip II and Alexander III of Macedon. This contributed to the maintenance of their collective consciousness of being different throughout the whole period of Roman government." (p. 98)

"The Romans did not have the goal of conducting a massive Romanisation of the population in Macedonia. It was impossible also because of the Macedonians' strong consciousness of belonging to a separate people." (p. 102)

"The Macedonians, during the whole period of the Roman government in Macedonia, were taking care and maintained the traditions related to their glorious past of the times of Philip II and Alexander III. This allowed them to keep their ethnic characteristics, such as their language, customs and clothing, and to maintain their role as a dominant people in Macedonia." (p. 102)

7 B. Ristovski et al., Istorija za prva godina gimnazisko obrazovanie, p. 5.

8 This provocative hypothesis has been promoted in several historical reviews and books. Cf. M.B. Panov, The Ancient Macedonians in Early Byzantium (4th $-6^{\text {th }}$ century): Attested Continuity, in: J. Donev, M.B. Panov, Z. Stefkovski (eds.), Macedonia between the Byzantine Commonwealth and the European Union, Skopje 2008, pp. 33-44 (published in Macedonian, with English abstract); Idem, Macedonia and the Macedonians in Byzantine Historiography $\left(\sigma^{\text {th }}-11^{\text {th }}\right.$ c.): Perception, Image, Construction, in: Macedonian Identity throughout the History. Materials from the international scientific conference held on the occasion of the $60^{\text {th }}$ anniversary from the foundation of the Institute of National History (Skopje, 10-12 October 2008), INI: Skopje 2010, pp. 43-66 (published in Macedonian). 
“That's why the Romanisation did not succeed to assimilate the Macedonian population linguistically and culturally, and the Macedonians continued to exist as a people throughout the whole period of the Roman government." (p. 103)

It is quite noticeable that these four quotations are in fact a tautology; in just a few pages (pp. 98-103) the author repeats the same opinion four times. Why would one bother to that? I consider this not to be neglect or literary incompetence on the author's part but, more likely, a method to ensure that by repeating the pupil will memorise and accept the proposed "knowledge". Putting the reader in the place of the pupil is the main reason why I chose the perilous approach of a long and repetitive quotation in this case.

What is questionable in the quoted excerpts? Contrary to the generally accepted theories (in Europe, the Balkans, and in Macedonia), a new, quite different and controversial interpretation of important historical processes is introduces in the school system. Evidently, the focus is on the process of Romanisation of the region of Macedonia and on the destiny of the ancient Macedonians, more precisely their group identity and culture. ${ }^{9}$ Although the Romanisation of the Balkan provinces is well documented by texts, inscriptions, architecture, names, etc., it is now proposed that this process had minimal effect on the local population and did not affect their group identity. The textbook argues that, on the one hand, the Romans did not conduct massive or violent Romanisation, and that, on the other hand, the ancient Macedonians had a very strong group identity and maintained their traditions. Contrary to this claim, it could be argued that the Romanisation did not necessarily have to be violent to be successful. Additionally, the role of the Roman legions as a strong means of massive Romanisation should not be neglected. As for the ancient Macedonians, it is quite logical that they more or less maintained their identity a few centuries after the Roman conquest. But claiming the same for the AD $6^{\text {th }} / 7^{\text {th }} \mathrm{c}$. (seven to eight centuries after the conquest) seems quite questionable. What evidence do we have of this? In fact, even if one doubts the effects of Romanisation, group identity in the Later Roman Empire mainly manifested itself in terms of citizenship (Roman), religion (Christian) and then region (e.g. Syrian). The written sources of the period do not indicate strong ethnic Macedonian feelings among the provincial population in Roman Macedonia.

The claim that the ancient Macedonians' language, customs and clothing were maintained until the $6^{\text {th }} / 7^{\text {th }} \mathrm{c}$. is completely frivolous. The textbook repeats this hypothesis several times, but does not provide any evidence (literary or material), which is actually to be expected since there are no sources whatsoever that would confirm

9 As I. Tarnanidis already argued in The Macedonians of the Byzantine Period, in: J. Burke and R. Scott (eds.), Byzantine Macedonia. Identity, Image and History (Papers from the Melbourne Conference July 1995), AABS: Melbourne, 2000 , p. 29 , any investigation into the relationship between antiquity and the present must take into consideration the influences that the specific populations were subject to as well as the transformations that they underwent. In the mentioned textbook, on the contrary, it seems that some of the possible transformations are minimized. 
this. All that is left of the language of the ancient Macedonians are some 150-200 glosses, which do not allow a linguistic reconstruction of the language. Knowledge about this language is very sparse even when one considers the times of Philip and Alexander, let alone Late Antiquity. ${ }^{10}$ As for the other proposed ethnicity markers, I would add that Late Antiquity sources do not support a distinction between the clothing habits of the population in Macedonia with those in the neighboring Roman provinces.

Contrary to the case of language, customs and clothing, the textbook proposes some literary evidence concerning the existence of ancient Macedonians in the city of Thessalonica in Late Antiquity. Three excerpts by early and middle Byzantine authors (Theodoret of Cyrus, the Miracles of Saint Demetrius, Simeon Metaphrast) are presented out of context and without the necessary or even basic historical explanation. ${ }^{11}$ What is stressed is the use of the word 'Macedonians' as proof that the ancient Macedonians still inhabited the late Roman cities in the $6^{\text {th }} / 7^{\text {th }} \mathrm{c}$. Then, the following question is posed to the students: "What was the ethnic composition of Solun in the period of the Slavic attacks?" 12 Since the quoted sources do not leave much room for interpretation, it is logically expected that the students should answer and learn that in the respective period Thessalonica was inhabited by the ancient Macedonians.

This claim is rather adventurous since the reconstruction of the ethnic picture is a quasi impossible task that would demand detailed epigraphic, literary, and other analyses. The quality and quantity of the sources on Thessalonica do not allow such an undertaking at this time. For example, the corpus of late Roman Christian inscriptions from Macedonia does not contain adequate information as to the ethnicity of the citizens. ${ }^{13}$ They usually state the citizens' family, God, and possibly their profession, but not their ethnicity - and all information is given in a very brief manner. In short, today we might be obsessed with their ethnicity, but in their own days they were not. There were other forms of group identity also. Or, in the words of Cameron: "By the early third century $\mathrm{AD}$ there was no longer any formal distinction in the empire between citizens and the non-citizens who formed the population of conquered or assimilated provinces; what mattered was not ethnicity or local background but shared culture, connections and status". ${ }^{14}$

As for the three quoted Byzantine authors, it is very important to note that the textbook does not take into consideration the literary traditions, the geographical and cultural knowledge in Late Antiquity in general, or of the authors in particular.

10 Cf. R.D. Woodward, The Ancient Languages of Europe, Cambridge University Press, 2008, pp. 9-11.

11 Cf. B. Ristovski et al., Istorija za prva godina gimnazisko obrazovanie, p. 145.

12 Ibid. Solun, the Slavic designation of Thessalonica.

13 See the solid study and collection of D. Feissel, Recueil des inscriptions chrétiennes de Macédoine du IIIe au VIe siècle, BCH suppl. 8, Ecole Française d'Athènes-Boccard : Athènes-Paris, 1983.

14 A. Cameron, The Byzantines, Blackwell: Malden-Oxford-Victoria, 2006, p. 8. For a similar opinion, cf. Tarnanidis, The Macedonians, p. 31: "In relation to other peoples, their defining characteristic was not their ancestry or their ethnic origins but their religion, their language, their culture, and their overall intellectual and spiritual identity". 
What is omitted is a well-known concept in the field of early Byzantine history, especially in the domain of literary tradition, i.e. the tendency among many late Roman and Byzantine authors to use classical names in the postclassical period, and even in later Byzantine times, as a form of imitation of the classical authors (their admired models). ${ }^{15}$ In that sense, there is an entire set of late Roman classicizing authors, such as Olympiodorus, Priscus, Malchus and others. Dealing with questions of ethnicity in the Byzantine world without any reference to this literary tradition is not a serious undertaking. The generally accepted knowledge in today's historiography holds that for Late Antiquity, as well as for later in Byzantium, the term Macedonia/ Macedonians has a regional/provincial/geographical meaning, and certainly not an ethnic one. ${ }^{16}$ In the words of Tarnanidis: "Throughout the whole of the so-called Middle Ages, Byzantine writers do not cease making reference to Macedonia, Macedonian Forces, and Macedonians. But the meaning of each term is unclear and its use not always synonymous. Thus, at various times the term 'Macedonia' covers more than one administrative district of the Roman, the Byzantine and later the Ottoman Empire, and none of them is ever permanent and stable". ${ }^{17}$ In short, using the term 'Macedonians' found in come Byzantine works while neglecting the context and literary tradition might be misleading.

"Reviving" the ancient Macedonians in the $6^{\text {th }} / 7^{\text {th }}$ c., the textbook confidently asks the pupils: "What was the mutual relationship between the Slavs and the ancient Macedonians and how did their mutual symbiosis develop?" 18 It is thus suggested that the existence of the ancient Macedonians in that period is a fact, and that the pupils should build further "knowledge" on this solid foundation. In another textbook the pupil reads: "After their installation, the Slavs found the ancient Macedonians in Macedonia", or even, "With a gradual mixture the Macedonian people was formed". ${ }^{19}$ In the most recent (2010) textbook, the 12-year-old pupils can

15 On this phenomenon in Byzantine times, with roots in Late Antiquity, cf. R. Scott, The Classical Tradition in Byzantine Historiography, in: M. Mullet and R. Scott (eds.), Byzantium and the Classical Tradition: University of Birmingham Thirteenth Spring Symposium of Byzantine Studies 1979, Birmingham 1981, pp. 61-74. A recent analysis on the use of ancient names in medieval Balkans and Byzantium to be found in O. Schmitt, "Mysians, Macedonians, Dardanians" - Some Remarks on late Medieval Ethnonyms in the Central Balkans, in: Macedonian Identity throughout the History. Materials from the international scientific conference held on the occasion of the $60^{\text {th }}$ anniversary from the foundation of the Institute of National History (Skopje, 10-12 October 2008), INI: Skopje 2010, pp. 73-78. Cf. also M.C. Bartusis, The Functions of Archaizing in Byzantium, Byzantinoslavica 56 (1995), pp. 271 278.

16 A detailed analysis of the signification of the term Macedonians can be found in Tarnanidis, The Macedonians, pp. 29-49, but I disagree with some of his conclusions. As for our topic, he finds the three principal meanings of the term 'Macedonians' in the early Byzantine period to be mainly geographical.

17 Ibidem, p. 31.

18 B. Ristovski et al., Istorija za prva godina gimnazisko obrazovanie, p. 146. 'Symbiosis' is a term, borrowed from biology, and used by many historians in the Balkans with the meaning of acculturation.

19 M. Boškoski, N. Derviši, S. Nadziri, D. Madzovski, S. Nikolovski, Istorija za prva godina gimnazisko obrazovanie, Prosvetno delo: Skopje, 2009, p. 164. (HT-1 ${ }^{\text {st }}$ class) 
still learn that the ancient Macedonians were already there when the Slavs arrived. ${ }^{20}$ The more recent textbooks do not elaborate on the controversial topic in detail, but they continue to promote the same message. Contrary to these examples, in 2001 pupils read that "in the Balkans, the Slavs came in contact with the autochthonous population. This population was mainly composed of: Byzantines (Romans), and Romanised Celts, Macedonians, Illyrians and Thracians", ${ }^{21}$ and that "these were the Romanised ancient Macedonians, Paionians, the descendants of the Roman colonists in Macedonia and others". ${ }^{22}$ Obviously, ancient Macedonians concept replaced the local Romanised population concept in the history textbooks.

It seems that this change in the historical narrative has an important but necessarily academic reason. While in the past there was a large gap between the ancient Macedonians and the Slavs, now this gap is being closed. By linking these two groups, one might now claim that the Macedonians of today have a direct "ethno-genetic" link with the ancient Macedonians and thus a new national myth can be fabricated. This is a point that the political elite seem to find very useful, particularly with regard to the name dispute with neighboring Greece.

Another interesting question in this respect is this: Where are the (Macedonian) Albanians in this search for ancient roots? It is quite new to note - albeit somewhat shyly - that the Albanians are linked with the ancient Illyrians. In 2006 we learn that:

[...] although there are not many written documents and other source-based arguments, the contemporary Albanian historiography accentuates the ties of the medieval Albanians with the Illyrians as a proven fact, supported by some archaeological, linguistic, ethnographic and anthropological research". ${ }^{23}$

Thus, the pupil is motivated to think: "Was there an ethnogenetic link between the Illyrians and the Arberians and how did this reflect on the culture?". ${ }^{24}$

In another textbook an entire chapter entitled "Illyrian-Albanian continuity" shows a more direct and confident attitude concerning this topic. After listing the few theories about the origins of the Albanians, the author continues: "The archaeological investigations in several Albanian regions confirm the ethno-cultural continuity of the Illyrians". ${ }^{25}$ The pupil, again, is motivated to accept this Illyrian-Albanian continuity. ${ }^{26}$ The main argument here is the specific Komani archaeological culture,

20 M. Boškoski, J. Ilioski, N. Derviši, Istorija za šesto oddelenie, Prosvetno delo: Skopje, 2010. (HT-6 ${ }^{\text {th }}$ grade).

21 K. Adzievski, J. Milčevski, Lj. Trajkovski, Istorija za šesto oddelenie, Tabernakul: Skopje, 2001, p. 24. (HT- $6^{\text {th }}$ grade) We find the same statement in another textbook: K. Adzievski, V. Ačkoska, Istorija za prva godina reformirano gimnazisko obrazovanie, Tabernakul: Skopje, 2002, p. 153. (HT-1 ${ }^{\text {st }}$ class).

22 K. Adzievski et al., Istorija za šesto oddelenie, p. 40.

23 B. Ristovski et al., Istorija za prva godina gimnazisko obrazovanie, p. 140.

24 Ibid., p. 141.

25 M. Boškoski et al., Istorija za prva godina gimnazisko obrazovanie, p. 158.

26 Ibid., p. 159. 
which covers one part of the territory of modern Albania and is characterised by its furnished cemeteries. It has been presented as a sign of Illyrian continuity, or at least revival, and as a link with the Albanians. Contrary to this, W. Bowden warns us about this kind of nationalistic interpretation and argues that the Komani culture is not an expression of ethnic identity, but a more localised and fluid social structures that emerged in post-Roman Epirus. ${ }^{27} \mathrm{He}$ claims that the population of this archaeological culture "participated in a European-wide medium of funerary practice, rather than constructing an identity that consciously expressed their difference from their neighbors" ${ }^{28}$ As additional arguments for the alleged Illyrian-Albanian continuity the textbook presents linguistics and the arts, especially music. These are topics which I would not feel prepared to deal with.

An immediate question is this: since it has always been regarded as hostile and artificial, how has this concept of Illyrian-Albanian continuity found its place in historiography and education in the R. of Macedonia? Since this is a very recent issue, one might wonder if it is a matter of political compromise between the Macedonian and Albanian political elites in Macedonia, in order to "peacefully" develop their respective national myths? I could only speculate about this question; therefore I leave the answer to the political scientists, sociologists and anthropologists.

In conclusion, I would argue that since 2006 new and more explicit forms of nationalist interpretation of late ancient history, which are flirting with pseudo-science, have entered the education system through certain history textbooks. Most of the proposed concepts are highly controversial, and sometimes have no foundation in the source material. Generally accepted knowledge is ignored and other, nationalistic, interpretations are given. By approving these textbooks, certain political institutions share the responsibility, and one can wonder if certain hypotheses are being favored because they are in accordance with the newest "national cause". This process affects the children in R. of Macedonia, especially those of the two biggest ethnic communities. Macedonian and Albanian pupils are taught their ancient roots, their autochthony, and their continuity with ancient Macedonians and Illyrians, respectively. The "ancient Macedonian" concept seems explicable by the intensifying name dispute with Greece, but also by the need to gain political points with the Macedonian part of the electorate. Still, it is important to note that the "continuity" narrative is not the only choice available. As an example, a textbook from 2006 offers a very different approach to history, allowing no space for the continuity myth. ${ }^{29}$

27 W. Bowden, The Construction of Identities in Post-Roman Albania, in: L. Lavan and W. Bowden (eds.), Theory and Practice in Late Antique Archaeology, Brill: Leiden-Boston, 2003, p. 57.

28 Ibid., p. 75.

29 K. Adzievski, D. Petreska, V. Ačkoska, D. Jovanovski, B. Emini, Istorija za prva godina sredno stručno obrazovanie, Tabernakul: Skopje, 2006. (HT-1 ${ }^{\text {st }}$ class) This particular textbook is a result of the FARE Program of the European Union implemented in the R. of Macedonia in order to contribute to the process of accepting EU standards and EU integration. It is interesting to note how some historians can produce such a different historical narrative and textbooks just one year apart. Cf. footnote 4 supra. 
Finally, it is fascinating that in the $21^{\text {st }} \mathrm{c}$. we can still find such scholarly inadequate and absurd concepts as autochthony, direct descend or ancient roots, in the education system. Not to mention the potentially dangerous aspect of this problem, since - bearing in mind the Yugoslav wars of the 1990s - it might lead to a deterioration of the already fragile image of the 'others', to territorial claims, and to a possible déjà vu scenario.

The question has arisen during the completion of this paper, whether analyzing only the nationalist myth in Macedonia will present a misleading picture of the situation concerning this problem in the Balkans, or more precisely whether it will depict Macedonia as the sole "abuser of history". I would emphasize one more that, as stated in the title, this paper is only a case study. Therefore, I have not tried to compare the different myths in the region. Any solid comparative study of this question, which would be an ideal accomplishment, requires several separate case studies as a starting point. ${ }^{30}$ In this sense, this paper pretends to be an eventual contribution to any future comparative approach to the politics of history education in the region.

\section{SAŽETAK}

\section{U potrazi za auhtohtnošću: studija o prikazima Velike seobe naroda u udžbenicima povijesti u Makedoniji}

Predmet analize u ovom članku segmenti su jednog značajnog povijesnog perioda, kao i njihovo mjesto u suvremenoj nastavi povijesti u Republici Makedoniji. Radi se o razdoblju Velike seobe naroda u kasnoj antici, konkretnije o dolasku Slavena na Balkan i o njihovim odnosima s lokalnim stanovništvom. Tri glavna zadatka analize bili su: 1. ispitati kako su spomenuti procesi prikazani učenicima osnovne i srednje škole, 2. usporediti predloženo „znanje“ s generalno prihvaćenim teorijama u suvremenoj historiografiji te 3. dobivene rezultate staviti u kontekst suvremene političke situacije, kako bi se detektirali eventualni politički utjecaji na obrazovanje.

Analizirani su adekvatni dijelovi iz nekoliko udžbenika koji tretiraju problem Velike seobe naroda. Svi su udžbenici pripremani od strane makedonsko-albanske

30 For the most recent detailed comparative study on national myths related to ancient history of the Balkans, cf. N. Proeva, Savremeni makedonski mit kao odgovor na nacionalne mitove suseda: albanski panilirizam, bugarski pantrakizam i grčki panhelenizam, Zgodovinski Časopis 64/1-2 (2010), pp. 176-219. For a wider picture of national myths in the Balkans, cf. P. Kolsto (ed.), Myths and Boundaries in South Eastern Europe, Hurst and Company: London, 2005; M. Todorova (ed.), Balkan Identities. Nation and Memory, New York University Press: New York, 2004; C. Koulouri (ed.), Clio in the Balkans. The Politics of History Education, CDRSEE: Thessaloniki, 2002. 
radne autorske ekipe i objavljeni nakon oružanog konflikta iz 2001 godine. Učenici koji imaju ulogu recipijenata predloženog materijala stari su 11, 12 i 15 godina.

U članku se iznosi teza da je putem spomenutih udžbenika učenicima prezentirana ideja autohtonosti, t.j. kontinuiteta između antičkih i suvremenih naroda na tlu Makedonije. Ova je veza uspostavljena na dva načina, od kojih je jedan neizravan, a drugi izravan. U većem dijelu teksta objašnjavaju se i razmatraju upravo tehnike stvaranja kontinuiteta između antičkih i današnjih naroda. Prva, indirektna i suptilna tehnika, upotrebljava kao glavno sredstvo neadekvatnu, nepreciznu, arhaizirajuću, pa čak i eventualno manipulativnu terminologiju. Preko koncepta „domovine“, koji najčešće nije jasno definiran, uspostavlja se implicitno određeni kronološki, „genetski“ i politički kontinuitet između države antičkih i suvremenih Makedonaca. Istovremeno se uvodi i pedagoški element kojim se naglasak stavlja na ideju borbe za domovinu te na učenje povijesti u školi kao neophodnog uvjeta za stvaranje ljubav prema domovini. Imajući na umu da u nekim udžbenicima koncept domovine nije adekvatno tretiran, moguće su određene komplikacije u budućnosti, kao teritorijalne pretenzije, porast nacionalizma, pa čak i konfliktne situacije. Druga tehnika, suprotno onome što je poznato i prihvaćeno u svjetskoj historiografiji, pokušava uvjeriti učenice u trajanje antičko-makedonske kulture, jezika, odijevanja i običaja koji su navodno ostali netaknuti do kraja antike, t.j. do dolaska Slavena (skoro osam stoljeća nakon propasti antičko-makedonske države), pa cak i kasnije. Tako, ako su početkom prvog desetljeća 21. stoljeća učenici u Makedoniji učili da su Slaveni prilikom dolaska na ovom prostoru zatekli romanizirano raznorodno stanovništvo, onda su u drugoj polovini tog istog desetljeća počeli učiti da su Slaveni tu zatekli „čistokrvni“ antički Makedonci, s jasno izraženom i sačuvanom etničkom sviješću i tradicijom. Pritom je proces romanizacije krajnje zanemaren. Nakon miješanja Slavena i antičkih Makedonaca stvoren je makedonski narod, koji je po toj logici isto toliko slavenski koliko je - ako ne i više - i antičko-makedonski. Jedini izvorni podatci koji su korišteni za izgradnju te tvrdnje su citati bizantskih autora koji povremeno spominju etnonim Makedonci. Ipak, valja naglasiti da su te reference preuzete bez bilo kakve kritičke analize i bez uzimanja u obzir već davno poznate literarne tendencije korištenja klasičnih imena za postklasični period, koja je već odavno uočena kod brojnih bizantskih autora. Učenicima nije ostavljena druga mogućnost nego da nauče kako je u kasnoj antici još uvijek egzistirao narod antičkih Makedonaca, i da na toj osnovi grade nove spoznaje. Slična je situacija i s mitovima makedonskih Albanaca jer se nekoliko posljednjih godina učenicima prezentira da su Iliri također postojali u kasnoj antici, sa svim svojim etno-kulturnim karakteristikama, kao i da postoji direktan ilirsko-albanski kontinuitet preko srednjovjekovlja do danas. Kao temelj za ove tvrdnje preuzima se specifična Komani arheološka kultura koja je postojala na velikom dijelu kasnorimske provincije Epir, usprkos tomu što vodeći svjetski arheolozi ne daju etničke atribute ovoj kulturi.

Na kraju, možemo zaključiti da su u posljednjih pet ili šest godina putem nekoliko udžbenika određene kontroverzne hipoteze ušle u nastavu povijesti u Makedoniji, na račun općeprihvaćene iz rimskih i bizantskih studija. Čini se da makedonske i alban- 
PoviJest U NASTAVI

ske političke elite u državi razvijaju svaka svoje nacionalne mitove, odgajajući svoje učenike u duhu nacionalizma, s konceptima kao autohtonost i antičko porijeklo, koji su akademski posve neadekvatni. Kad uzmemo u obzir ne tako davne jugoslavenske ratove, kao i uloge nacionalističkih mitova u tom kontekstu, očigledne su sve moguće komplikacije koje može izazvati ovakav pristup povijesti, osobito kada je zastupljen i u nastavi. 